JEKK $\quad \begin{gathered}\text { Jurnal Epidemiologi Kesehatan Komunitas } \\ 3(1), 2018,41-47\end{gathered}$

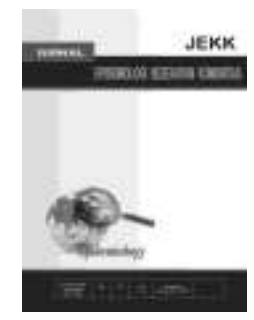

\title{
Beberapa Faktor Risiko Kejadian Campak Pada Balita di Kabupaten Sarolangun
}

\author{
Mostang Arianto ${ }^{*}$, Mexitalia Setiawati ${ }^{* *}$, Sakundarno Adi ${ }^{* * *}$, Suharyo Hadisaputro ${ }^{* * * *}$, \\ Kamilah Budhi** \\ *Dinas Kesehatan Kabupaten Sarolangun, **Fakultas Kedokteran Universitas Diponegoro, \\ ${ }^{* * * *}$ Fakultas Kesehatan Masyarakat Universitas Diponegoro, ${ }^{* * * *}$ Politeknik Kesehatan \\ Semarang
}

\begin{abstract}
Background: Measles is a highly infectious disease caused by the measles virus and is still a health problem in Indonesia. Based on data the communicable disease surveillance system from 2014 to January 2016 have been reported cases of measles as many as 200 cases. This study aims to explain host and environment factors as risk factors for occurrence of measles in children under five years old.

Method: A case control study, involving 56 cases children under five years old suffer from measles were registered in form $\mathrm{C} 1$ of health center, with 56 sex matched neighborhood controls. Studied variables were analyzed by multivariate.

Result: Risk factors for measles occurrence were living at unhealthy house $(\mathrm{OR}=7.5 ; 95 \%$ $\mathrm{CI}=2.64$ to 21.19), low of mother's knowledge $(\mathrm{OR}=5.7 ; 95 \% \mathrm{CI}=2.22$ to 14.85$)$, and never received immunization $(\mathrm{OR}=3.7 ; 95 \% \mathrm{CI}=1.45$ to 9.39$)$. Risk factors not proved with measles occurrence were malnutrition, lack of vitamin A, never had measles, contact history, breast-fed $<2$ years, maternal age $<20$ years, low of socio-economic, number of children under five years old at home $>1$ and less parenting.

Conclusion: Risk factors associated with measles were living at unhealthy house, low of mother's knowledge and never received vaccination. For elimination, measles vaccination, home inspection, communication, information and education of measles is required.
\end{abstract}

Keywords: Risk factors; measles; children; Sarolangun

*Penulis korespondensi : $\underline{\text { mostang.arianto@yahoo.co.id }}$ 


\section{Pendahuluan}

Campak adalah suatu penyakit yang sangat menular yang disebabkan oleh virus campak. ${ }^{1}$ Sekitar $90 \%$ dari yang mengalami kontak dengan campak akan terkena infeksi ${ }^{2}$ WHO menyatakan bahwa jumlah kematian akibat campak meningkat dari taksiran 122.000 di tahun 2012 menjadi 145.700 tahun 2013. ${ }^{3}$ WHO untuk wilayah Asia Tenggara menyebutkan bahwa pada tahun 1990 terjadi 218.029 kasus campak dan kemudian menurun menjadi 114.531 kasus pada tahun 1997. Sedangkan untuk wilayah Indonesia pada tahun 1990 dilaporkan 92.105 kasus dan kemudian menjadi 15.313 kasus pada tahun $1997^{4}$. Profil Kesehatan Indonesia tahun 2012, kasus penyakit campak sebanyak 15.489 kasus dan Incidence Rate (IR) sebesar 6,5 per 100.000 penduduk $^{5}$, sedangkan tahun 2013 turun menjadi 11.521 kasus campak dan Incidence Rate (IR) sebesar 4,64 per 100.000 penduduk.

Campak mengalami penurunan tetapi masih menempati urutan ke lima dari 10 penyakit utama pada balita ${ }^{6}$. Riskesdas 2007, prevalensi penyakit campak di Kabupaten Sarolangun sebesar 4,4\% dan tertinggi di Provinsi Jambi. ${ }^{7}$ Di Kabupaten Sarolangun tahun 2014 terjadi Kejadian Luar Biasa di 5 puskesmas sebanyak 213 kasus dengan Incidence Rate (IR) sebesar 78,3 per 100.000 penduduk. Kasus terbanyak terjadi pada anak balita sebesar 140 kasus (66\%), tahun 2015 KLB di puskesmas Limbur Tembesi sebanyak 42 kasus dan sampai bulan Januari 2016 sebanyak 18 kasus di puskesmas yang sama. ${ }^{8}$ Berbagai faktor host yang diduga berpengaruh terhadap kejadian campak pada balita adalah faktor anak (status imunisasi, umur saat imunisasi, status gizi, riwayat kontak, riwayat penyakit campak, pemberian Vit A), faktor ibu (tingkat pendidikan ibu, tingkat pengetahuan ibu, pendapatan). Berbagai faktor environment yang diduga berpengaruh terhadap kejadian campak yaitu keadaan rumah, jumlah balita dalam rumah, persepsi dan pola asuh anak.
Penelitian ini bertujuan mengidentifikasi faktor-faktor risiko kejadian campak pada balita di Kabupaten Sarolangun.

\section{Metode}

Penelitian ini menggunakan desain studi case control. Penelitian ini dilakukan di Kabupaten Sarolangun periode tahun 2014 sampai Mei 2016. Sampel penelitian adalah anak dibawah lima tahun menderita campak yang berkunjung ke puskesmas periode tahun 2014-Mei 2016 yang tercatat dalam laporan $\mathrm{Cl}$ campak puskesmas yang memenuhi kriteria inklusi dan eksklusi. Jumlah kasus sebanyak 56 responden dengan cara consecutive sampling dan 56 responden sebagai kontrol yang merupakan tetangga kasus dengan matching jenis kelamin.

Alat pengumpulan data adalah kuesioner yang digunakan untuk mengumpulkan data karakteristik responden dan mencatat adanya faktor risiko campak. Data diolah dengan menggunakan software statistik dan analisis data yang digunakan antara lain analisis univariat, analisis bivariat dengan uji statisti Chi Square serta analisis multivariat dengan uji regresi logistik.

\section{Hasil}

\section{Hubungan antara variabel independen dengan kejadian campak pada balita}

Tabel 1. menunjukkan ada hubungan yang bermakna antara pengetahuan ibu kurang, rumah tidak sehat, tidak diimunisasi campak, pola asuh kurang dan lama diberi ASI $<2$ tahun dengan kejadian campak ( $p$ $<0,05)$. Dari analisis bivariat, terdapat empat variabel yang merupakan faktor risiko yaitu pengetahuan ibu kurang, rumah tidak sehat, tidak diimunisasi campak dan pola asuh kurang 
Tabel 1. Hubungan Variabel Independen terhadap Keiadian Campak pada Balita

\begin{tabular}{|c|c|c|c|c|c|c|c|c|}
\hline \multirow[t]{2}{*}{ No } & \multirow[t]{2}{*}{ Variabel } & \multicolumn{2}{|c|}{ Kasus } & \multicolumn{2}{|c|}{ Kontrol } & \multirow[t]{2}{*}{$95 \% \mathrm{CI}$} & \multirow[t]{2}{*}{ OR } & \multirow[t]{2}{*}{$p$ value } \\
\hline & & $\mathrm{n}$ & $\%$ & $\mathrm{n}$ & $\%$ & & & \\
\hline \multirow[t]{4}{*}{1} & Status imunisasi & & & & & & & \\
\hline & Tidak diimunisasi & 29 & 51,8 & 13 & 23,2 & $1,58-8,00$ & 3,6 & 0,002 \\
\hline & Diimunisasi & 27 & 48,2 & 43 & 76,8 & & & \\
\hline & Total & 56 & 100,0 & 56 & 100,0 & & & \\
\hline \multirow[t]{4}{*}{2} & Status gizi & & & & & & & \\
\hline & Gizi kurang & 6 & 10,7 & 13 & 23,2 & $0,14-1,13$ & 0,4 & 0,078 \\
\hline & Gizi baik & 50 & 89,3 & 43 & 76,8 & & & \\
\hline & Total & 56 & 100,0 & 56 & 100,0 & & & \\
\hline \multirow[t]{4}{*}{3} & Pemberian Vitamin A & & & & & & & \\
\hline & Kurang & 28 & 50 & 20 & 35,7 & $0,84-3,84$ & 1,8 & 0,127 \\
\hline & Baik & 28 & 50 & 36 & 64,3 & & & \\
\hline & Total & 56 & 100 & 56 & 100,0 & & & \\
\hline \multirow[t]{4}{*}{4} & Lama diberi ASI & & & & & & & \\
\hline & $<2$ tahun & 42 & 75 & 50 & 89,3 & $0,13-1,02$ & 0,4 & 0,048 \\
\hline & $>=2$ tahun & 14 & 25 & 6 & 10,7 & & & \\
\hline & Total & 56 & 100 & 56 & 100,0 & & & \\
\hline \multirow[t]{4}{*}{5} & Riwayat kontak & & & & & & & \\
\hline & Pernah & 27 & 48,2 & 18 & 32,1 & $0,91-4,24$ & 1,9 & 0,083 \\
\hline & Tidak pernah & 29 & 51,8 & 38 & 67,9 & & & \\
\hline & Total & 56 & 100,0 & 56 & 100,0 & & & \\
\hline \multirow[t]{4}{*}{6} & Umur ibu & & & & & & & \\
\hline & $<20$ tahun & 2 & 3,6 & 1 & 1,8 & $0,18-23,13$ & 2,0 & 1,000 \\
\hline & $>=20$ tahun & 54 & 96,4 & 55 & 98,2 & & & \\
\hline & Total & 56 & 100,0 & 56 & 100,0 & & & \\
\hline \multirow[t]{4}{*}{7} & Pengetahuan ibu & & & & & & & \\
\hline & Kurang & 35 & 62,5 & 15 & 26,8 & $2,04-10,15$ & 4,6 & 0,0001 \\
\hline & Baik & 21 & 37,5 & 41 & 73,2 & & & \\
\hline & Total & 56 & 100,0 & 56 & 100,0 & & & \\
\hline \multirow[t]{4}{*}{8} & Sosial ekonomi & & & & & & & \\
\hline & Rendah & 4 & 7,1 & 8 & 14,3 & $0,13-1,63$ & 0,5 & 0,222 \\
\hline & Tinggi & 52 & 92,9 & 48 & 85,7 & & & \\
\hline & Total & 56 & 100,0 & 56 & 100,0 & & & \\
\hline \multirow[t]{4}{*}{9} & Kondisi rumah & & & & & & & \\
\hline & Tidak sehat & 46 & 82,1 & 26 & 46,4 & $2,24-12,57$ & 5,3 & 0,0001 \\
\hline & Sehat & 10 & 17,9 & 30 & 53,6 & & & \\
\hline & Total & 56 & 100,0 & 56 & 100,0 & & & \\
\hline \multirow[t]{4}{*}{10} & Jumlah balita dalam rumah & & & & & & & \\
\hline & $>1$ orang & 6 & 10,7 & 8 & 14,3 & $0,23-2,23$ & 0,7 & 0,568 \\
\hline & 1 orang & 50 & 89,3 & 48 & 85,7 & & & \\
\hline & Total & 56 & 100,0 & 56 & 100,0 & & & \\
\hline \multirow[t]{4}{*}{11} & Pola Asuh & & & & & & & \\
\hline & Kurang & 34 & 60,7 & 19 & 33,9 & $1,39-6,50$ & 3,0 & 0,005 \\
\hline & Baik & 22 & 39,3 & 37 & 66,1 & & & \\
\hline & Total & 56 & 100,0 & 56 & 100,0 & & & \\
\hline \multirow[t]{4}{*}{12} & Riwayat penyakit campak & & & & & & & \\
\hline & Tidak pernah & 56 & 100,0 & 54 & 96,4 & - & - & 0,497 \\
\hline & Pernah & 0 & 0,0 & 2 & 3,6 & & & \\
\hline & Total & 56 & 100,0 & 56 & 100,0 & & & \\
\hline
\end{tabular}


Hasil uji statistik menunjukkan ibu yang berpengetahuan kurang balitanya berisiko 4,6 kali lebih besar terkena campak dibandingkan ibu berpengetahuan baik $(95 \% \mathrm{CI}=2,04-10,15$; $\mathrm{OR}=4,6$ ). Balita yang tinggal di rumah tidak sehat berisiko 5,3 kali lebih besar terkena campak dibandingkan balita yang tinggal di rumah sehat $(95 \% \mathrm{CI}=2,24-12,57 ; \quad \mathrm{OR}=5,3)$. Balita yang tidak diimunisasi campak berisiko 3,6 kali lebih besar terkena campak dibandingkan balita yang diimunisasi campak $(95 \% \mathrm{CI}=1,58-8,00 ; \mathrm{OR}=3,6)$. Pola asuh ibu kurang balitanya berisiko 3 kali lebih besar terkena campak dibandingkan pola asuh ibu baik.

\section{Faktor yang paling berpengaruh terhadap kejadian campak pada balita}

Hasil analisis bivariat (Tabel 1) terdapat sembilan variabel kandidat untuk analisis multivariat dengan nilai $p<0,25$ yaitu rumah tidak sehat, pengetahuan ibu kurang, tidak diimunisasi campak, pola asuh kurang, ada riwayat kontak, pemberian vitamin A kurang, gizi kurang, lama diberi ASI $<2$ tahun dan sosial ekonomi rendah.

Hasil analisis multivariat pada tabel 3, terdapat tiga variabel yang paling berpengaruh terhadap kejadian campak pada balita yaitu pengetahuan ibu kurang, tidak diimunisasi campak dan rumah tidak sehat. Ibu berpengetahuan kurang balitanya berisiko 5,7 kali lebih besar terkena campak dibandingkan ibu berpengetahuan baik $(95 \% \mathrm{CI}=2,22-14,85$; $\mathrm{OR}=5,7)$. Balita tidak diimunisasi campak berisiko 3,7 kali lebih besar terkena campak dibandingkan balita yang diimunisasi campak $(95 \% \mathrm{CI}=1,45-9,39 ; \quad \mathrm{OR}=3,7)$. Balita yang tinggal di rumah tidak sehat berisiko 7,5 kali lebih besar terkena campak dibandingkan balita yang tinggal di rumah sehat $(95 \% \mathrm{CI}=2,64-$ 21,19; OR=7,5).
Tabel 2. Variabel Paling Kuat merupakan Faktor Risiko Campak pada Balita

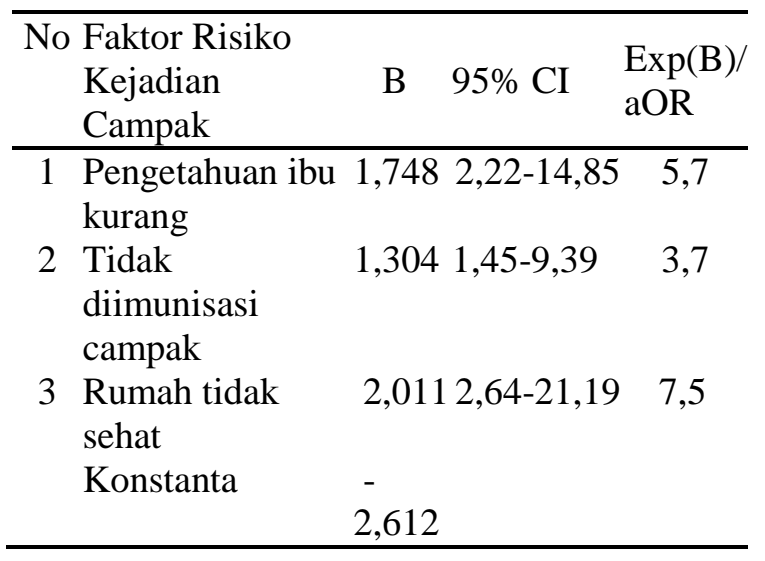

Hasil perhitungan persamaan probability event dari hasil analisis uji multiple logistic regression $\mathrm{di}$ atas terbukti bahwa pengetahuan ibu kurang, tidak diimunisasi campak dan rumah tidak sehat memiliki probabilitas menderita campak pada balita sebesar $92,08 \%$.

\section{Pembahasan}

\section{Tidak Imunisasi Campak}

Imunisasi adalah upaya untuk meningkatkan kekebalan individu agar tahan terhadap penyakit yang sedang mewabah atau berbahaya bagi kesehatan $^{9-11}$. Tujuan diberikannya imunisasi adalah untuk mengurangi angka penderita suatu penyakit yang sangat membahayakan kesehatan bahkan bisa menyebabkan kematian pada penderitanya,mencegah penyakit menular dan tubuh tidak akan mudah terserang penyakit menular ${ }^{10,11}$. Hasil penelitian ini menunjukkan bahwa tidak diimunisasi campak terbukti sebagai faktor risiko terhadap kejadian campak pada balita. Status imunisasi erat kaitannya dengan cakupan imunisasi, data Riset Kesehatan Dasar tahun 2013 bahwa cakupan imunisasi campak di Kabupaten Sarolangun sebesar 98,2\% dan data Dinas 
Kesehatan tahun 2014 sebesr 98\% yang artinya kekebalan komunitas (herd immunity) sudah diatas $95 \%$, tetapi kasus campak masih terjadi. Kemungkinan hal ini dapat disebabkan oleh ketidaktepatan dalam membuat perkiraan target sasaran imunisasi, kemungkinan kedua karena data laporan kurang valid atau vaksin tidak efektif karena pengelolaan vaksin yang salah. Pengamatan di lapangan prosedur penanganan vaksin tidak sesuai prosedur, cold chain tidak pernah dikalibrasi, pemantauan suhu tidak pernah dilakukan bahkan suhu mencapai $22^{\circ} \mathrm{C}$ dan petugas pengelola vaksin sebanyak $25 \%$ adalah lulusan SPK dan tidak pernah mendapatkan pelatihan pengelolan vaksin. Menurut WHO, jika cakupan imunisasi sudah mencapai > 90\%, tetapi masih terjadi kasus campak yang perlu diperhatikan adalah cold chain vaksin dan tingkat kebenaran hasil laporan cakupan imunisasi campak.

Hasil penelitian ini sejalan dengan penelitian yang dilakukan oleh Zahidie, et $a l^{12}$ yang menunjukkan bahwa anak yang tidak mendapatkan imunisasi campak mempunyai resiko sebesar 10,1 kali untuk terkena campak (95\% CI=4,5-22,5). Hasil wawancara mendalam menunjukkan bahwa ada beberapa alasan bayi tidak mendapatkan imunisasi, namun yang menjadi perhatian, petugas kesehatan diharapkan proaktif khususnya bidan desa yang melakukan imunisasi di posyandu setiap bulan dengan melakukan sweeping terhadap bayi yang tidak datang imunisasi. Penyampaian informasi jadwal imunisasi penting diperhatikan oleh petugas kesehatan dengan bantuan kader-kader posyandu. Selain itu koordinator imunisasi puskesmas diharapkan rutin melakukan evaluasi pelaksanaan imunisasi di desa sehingga target sasaran yang tidak tercapai dapat diatasi dengan baik.

\section{Rumah Tidak Sehat}

Rumah merupakan salah satu kebutuhan pokok manusia, disamping kebutuhan sandang dan pangan. Rumah berfungsi sebagai tempat tinggal serta digunakan untuk berlindung dari gangguan iklim dan mahluk hidup lainnya. Rumah juga merupakan tempat berkumpulnya anggota keluarga untuk menghabiskan sebagian besar waktunya. Bahkan bayi, anak-anak, orang tua dan orang sakit menghabiskan hampir seluruh waktunya di rumah. Pengertian rumah sehat menurut Kepmenkes nomor 829/1999 adalah kondisi fisik, kimia, biologis di dalam rumah, lingkungan rumah dan perumahan sehingga memungkinkan penghuni atau masyarakat memperoleh derajat kesehatan yang optimal. ${ }^{13}$

Berdasarkan hasil penelitian ini menunjukkan bahwa rumah tidak sehat terbukti secara statistik sebagai faktor risiko terhadap kejadian campak pada balita. Rumah tidak sehat berhubungan dengan kejadian campak mungkin disebabkan karena $64,3 \%$ responden masih tinggal di rumah tidak sehat, selain itu data Dinas Kesehatan Kabupaten Sarolangun menunjukkan bahwa sekitar 41\% masyarakat masih memiliki rumah papan dan semi permanen Penelitian ini bila dibandingkan dengan penelitian lain berdasarkan komponen rumah tidak berbeda jauh, menurut penelitian Casaeri menunjukkan bahwa kepadatan hunian merupakan faktor risiko kejadian campak $(\mathrm{OR}=2,6)^{14}$, penelitian Iswandi menunjukkan ventilasi rumah merupakan faktor risiko campak $(\mathrm{OR}=44,62)^{15}$.

Sebuah rumah dikatakan sehat bila memenuhi persyaratan pencegahan penularan penyakit antar penghuni rumah dengan penyediaan air bersih, pengelolaan tinja dan limbah rumah tangga, bebas vektor penyakit dan tikus, kepadatan hunian yang tidak berlebihan, cukup sinar matahari pagi, terlindungnya makanan dan minuman dari pencemaran, disamping pencahayaan dan penghawaan yang cukup. 16

Hasil wawancara mendalam menunjukkan bahwa masyarakat dalam 
membangun rumah belum memperhatikan aspek kesehatan, yang penting bagi mereka ada tempat berlindung dan beristirahat bagi anggota keluarga dari panas dan hujan. Karena itu pentugas kesehatan lingkungan puskesmas diharapkan rutin setiap bulan melakukan inspeksi rumah dalam meningkatkan wawasan masyarakat pentingnya rumah sehat.

\section{Pengetahuan ibu kurang}

Pengetahuan merupakan hal yang sangat penting dalam membentuk tindakan seseorang. ${ }^{17}$ Teori cognitive consistency bahwa terdapat hubungan konsisten dalam diri seseorang yaitu pengetahuan, sikap dan perilaku. Perilaku dapat diubah dengan cara merubah pengetahuan dan sikap. Proses pendidikan akan berpengaruh pada perubahan pengetahuan dan merubah sikap seseorang yang akan menghasilkan perubahan pada perilaku. Pengetahuan dapat diperoleh seseorang melalui berbagai macam alat bantu seperti media cetak, media elektronik (televisi, radio, video, slide) dan media papan yang berisi pesan kesehatan. $^{18}$

Hasil penelitian ini menunjukkan bahwa pengetahuan ibu kurang secara statistik terbukti sebagai faktor risiko terhadap kejadian campak pada balita. Secara umum masyarakat memiliki pengetahuan yang kurang tentang campak, penyebab dan cara penularannya. Pemahaman masyarakat bahwa campak merupakan penyakit demam biasa, selain itu seseorang wajib terkena campak satu kali seumur hidup, sehingga lebih baik terkena campak pada saat anak-anak supaya tidak parah. Pengobatan yang dilakukan dengan memberikan air kelapa muda supaya ruam merahnya cepat keluar dengan asumsi bila ruam merah tidak cepat keluar akan membahayakan, selain itu anak tidak diperbolehkan mandi. Hasil penelitian ini juga sesuai dengan teori Lawrence Green pada predisposing factors, bahwa pengetahuan merupakan peran kunci dalam pemeliharaan kesehatan dan pencegahan penyakit serta peningkatan keamanan karena pengetahuan tentang anjuran untuk praktek kesehatan penting dalam menentukan pilihan terbaik seperti mengimunisasi bayi dan balita secara lengkap. ${ }^{17}$ Hasil penelitian ini juga tidak berbeda dengan penelitian Iswandi $^{15}$ yang menunjukkan bahwa pengetahuan ibu kurang merupakan faktor risiko terhadap kejadian campak $(\mathrm{OR}=6,03)$.

\section{Kesimpulan}

Faktor yang terbukti merupakan faktor risiko terhadap kejadian campak pada balita yaitu tidak diimunisasi campak, rumah tidak sehat dan pengetahuan ibu kurang dengan probability event sebesar 92,08\%. Faktorfaktor yang tidak terbukti sebagai faktor risiko terhadap kejadian campak pada balita yaitu gizi kurang, pemberian vitamin A kurang, tidak pernah menderita campak sebelumnya, ada riwayat kontak, lama diberi ASI $<2$ tahun, umur ibu $<20$ tahun, sosial ekonomi rendah, jumlah balita dalam rumah $>1$ orang dan pola asuh kurang.

\section{Ucapan Terimakasih}

Terimakasih kepada masyarakat kelompok kasus dan kontrol (kejadian campak) di Kabupaten Sarolangun sebagai sampel penelitian dan berbagai pihak yang telah membantu pengumpulan data.

\section{Daftar Pustaka}

1. Chin J. Manual pemberantasan penyakit menular. 17th ed. Kandun NI, editor. Jakarta: CV. Infomedika; 2006. 344-350 p.

2. Widagdo. Masalah dan Tatalaksana Penyakit Anak dengan Deman. 1st ed. Mariyam, editor. Jakarta: CV. Sagung Seto; 2011. 133-134 p. 
3. World Health Organization. WHO warns that progress towards eliminating measles has stalled [Internet].2014. Available from http://www.who.int/mediacentre/news/rele ases/2014/eliminating-measles/en/

4. CDC. Measles Control-South Est Asia Region, 1990-1997. 1999;48(25);541. Available from https://www.cdc.gov/mmwr/preview/mm wrhtml/mm6033a3.htm

5. Kementerian Kesehatan RI. Profil Kesehatan Indonesia Tahun 2012. Jakarta; 2012.

6. Kementerian Kesehatan RI. Profil Data Kesehatan Indonesia Tahun 2013. Jakarta; 2013.

7. Departemen Kesehatan RI. Riset Kesehatan Dasar Provinsi Jambi Tahun 2007.

8. Dinas Kesehatan Kabupaten Sarolangun. Profil Kesehatan Tahun 2014.

9. Suharjo B. Vaksinasi Cara Ampuh Cegah Penyakit Infeksi. 5th ed. Prabawa H, editor. Yogyakarta: Kanisius; 2010. 81- 83 p.

10. Lisnawati L. Generasi Sehat Melalui Imunisasi. 1st ed. Jakarta: CV. Trans Info Media; 2011.97 p.

11. Siti N. Imunisasi Untuk Anak. 1st ed. Yogyakarta: Nuha Medika; 2013. 5-6 p.
12. Zahidie A, Wasim S, Fatmi Z. Vaccine Effectiveness and Risk Factors Associated with Measles Among Children Presenting to the Hospitals of Karachi , Pakistan. 2014;24(12):882-8.

13. Kementerian Kesehatan RI. Keputusan Menteri Kesehatan RI No. $\quad$ 829/Menkes/SK/VII/1999

Tentang Persyaratan Kesehatan Perumahan. Jakarta; 1999.

14. Casaeri. Faktor-faktor risiko kejadian penyakit campak di Kabupaten Kendal tahun 2002. Universitas Diponegoro; 2003.

15. Iswandi. Faktor-faktor yang berhubungan dengan kejadian campak pada anak usia 9-59 bulan di perkebunan kelapa sawit P.T. Musim Mas Kecamatan Pangkalan Lesung Kabupaten Pelalawan tahun 2002.

16. Departemen Kesehatan RI. Pedoman Teknis Penilaian Rumah Sehat. 2007.

17. Notoatmodjo S. Promosi Kesehatan dan Ilmu Perilaku. Jakarta: Rineka Cipta; 2007.

18. Notoatmodjo S. Promosi Kesehatan dan Ilmu Perilaku Teori dan Aplikasi. Jakarta: Rineka Cipta; 2005 
